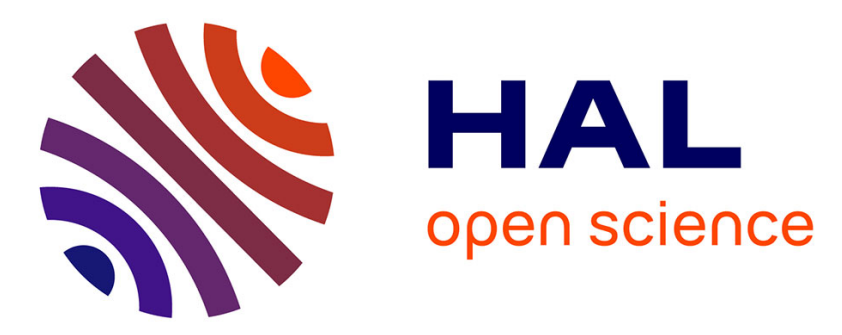

\title{
Expression analysis of facilitative glucose transporters (GLUTs) in human thyroid carcinoma cell lines and primary tumors
}

Raffaele Ciampi, Agnese Vivaldi, Cristina Romei, Alberto del Guerra, Piero Salvadori, Barbara Cosci, Aldo Pinchera, Rossella Elisei

\section{To cite this version:}

Raffaele Ciampi, Agnese Vivaldi, Cristina Romei, Alberto del Guerra, Piero Salvadori, et al.. Expression analysis of facilitative glucose transporters (GLUTs) in human thyroid carcinoma cell lines and primary tumors. Molecular and Cellular Endocrinology, 2008, 291 (1-2), pp.57. 10.1016/j.mce.2008.05.003 . hal-00532026

\section{HAL Id: hal-00532026 https://hal.science/hal-00532026}

Submitted on 4 Nov 2010

HAL is a multi-disciplinary open access archive for the deposit and dissemination of scientific research documents, whether they are published or not. The documents may come from teaching and research institutions in France or abroad, or from public or private research centers.
L'archive ouverte pluridisciplinaire HAL, est destinée au dépôt et à la diffusion de documents scientifiques de niveau recherche, publiés ou non, émanant des établissements d'enseignement et de recherche français ou étrangers, des laboratoires publics ou privés. 


\section{Accepted Manuscript}

Title: Expression analysis of facilitative glucose transporters (GLUTs) in human thyroid carcinoma cell lines and primary tumors

Authors: Raffaele Ciampi, Agnese Vivaldi, Cristina Romei, Alberto Del Guerra, Piero Salvadori, Barbara Cosci, Aldo

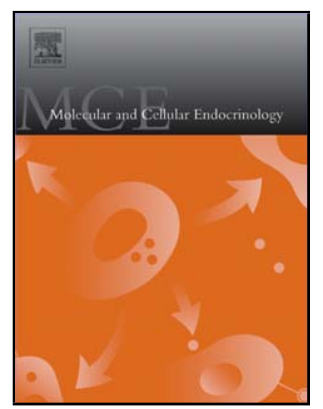

Pinchera, Rossella Elisei

PII:

S0303-7207(08)00222-0

DOI: doi:10.1016/j.mce.2008.05.003

Reference: MCE 6878

To appear in: Molecular and Cellular Endocrinology

Received date: $18-12-2007$

Revised date: $3-4-2008$

Accepted date: $7-5-2008$

Please cite this article as: Ciampi, R., Vivaldi, A., Romei, C., Del Guerra, A., Salvadori, P., Cosci, B., Pinchera, A., Elisei, R., Expression analysis of facilitative glucose transporters (GLUTs) in human thyroid carcinoma cell lines and primary tumors, Molecular and Cellular Endocrinology (2007), doi:10.1016/j.mce.2008.05.003

This is a PDF file of an unedited manuscript that has been accepted for publication. As a service to our customers we are providing this early version of the manuscript. The manuscript will undergo copyediting, typesetting, and review of the resulting proof before it is published in its final form. Please note that during the production process errors may be discovered which could affect the content, and all legal disclaimers that apply to the journal pertain. 


\title{
EXPRESSION ANALYSIS OF FACILITATIVE GLUCOSE TRANSPORTERS (GLUTS) IN HUMAN THYROID CARCINOMA CELL LINES AND PRIMARY TUMORS
}

\author{
Raffaele Ciampi ${ }^{1}$, Agnese Vivaldi ${ }^{1}$, Cristina Romei, ${ }^{1}$ Alberto Del Guerra ${ }^{2,4}$, Piero Salvadori ${ }^{3}$, \\ Barbara $\operatorname{Cosci}^{1}$, Aldo Pinchera ${ }^{1,4}$ and Rossella Elisei ${ }^{1}$
}

${ }^{1}$ Department of Endocrinology and Metabolism, University of Pisa, Italy

${ }^{2}$ Department of Physics, University of Pisa, Italy

${ }^{3}$ Department of Clinical Physiology, C.N.R. Pisa, Italy

${ }^{4}$ AMBISEN Center, High Technology Center for the Study of the Environmental Damage of the Endocrine and Nervous Systems, University of Pisa, Italy

\footnotetext{
Corresponding author:

Dr Rossella Elisei

Department of Endocrinology and Metabolism

University of Pisa

Via Paradisa, 2

56124 Pisa, Italy

Phone: +39 050-995120

Fax: +39 050-578772

E-mail address: relisei@endoc.med.unipi.it
} 


\section{ABSTRACT}

Fluorine-18-fluoro-2-deoxy-D-glucose positron emission tomography (FDG-PET) is based on cell capability to take-up glucose. While a significantly higher expression of the glucose transporter GLUT1 has been reported in thyroid tumors only few data are available on the expression of other GLUT isoforms.

We studied several GLUT isoforms expression in thyroid tumor cell lines deriving from anaplastic (ARO, FRO), papillary (NPA), follicular (WRO) and medullary (TT) human thyroid carcinoma. GLUT1 and GLUT3 were also studied in 157 human thyroid malignant and benign tissues.

Quantitative Real-time RT-PCR analysis revealed that GLUT1 mRNA levels were higher in less-differentiated cells (ARO, FRO) while GLUT3 mRNA levels were prevalent in well-differentiated cells (NPA, WRO). Accordingly, Western blot showed high expression and correct membrane targeting of GLUT1 protein in ARO and FRO and of GLUT3 protein in NPA and WRO. All cell lines were able to take-up different rates of ${ }^{3}$ H-Deoxy-Glucose. The analysis of GLUT1 and GLUT3 mRNA expression in human thyroid tissues showed the prevalence of GLUT1, but not of GLUT3, in malignant with respect to normal tissues. Finally, both GLUT1 and GLUT3 showed a slightly higher expression in anaplastic than in well-differentiated tumors.

In conclusion, we showed that GLUT1 and GLUT3 were the most important glucose transporters in the thyroid tumoral cells. In particular GLUT1 was the most prevalent in less-differentiated cells (ARO and FRO) while GLUT3 was the most prevalent in welldifferentiated cells (NPA and WRO). A similar pattern of expression was found for GLUT1 but not for GLUT3 in human thyroid tumors. 


\section{INTRODUCTION}

It has been extensively described that tumor cells are characterized by increased requirement for energy that, together with a reduced ability to use oxidative in favor to glycolitic pathways, results in higher glucose requirement (Hatanaka, 1974, Isselbacher, 1972a, Isselbacher, 1972b). This is the basis for Fluorine-18-fluoro-2-deoxy-D-glucose (18FDG) positron emission tomography (FDG-PET) (Kresnik et al., 2003) that employs 18FDG, a glucose analog, as tracer. Today, FDG-PET represents one of the most powerful imaging diagnostic tools utilized in the diagnosis of different human tumors (Scott, 2001, Strauss and Conti, 1991). Several reports indicate its usefulness in the follow-up of differentiated thyroid cancers, especially when they are not able to take-up iodine anymore. In these de-differentiated tumors, a positive FDG-PET has been demonstrated to have an unfavorable prognostic value (Frilling et al., 2001, Grunwald et al., 1999, Plotkin et al., 2002, Stokkel et al., 2006). This finding together with the evidence that most of anaplastic thyroid carcinomas (ATC) are usually well detected by FDG-PET (Conti et al., 1999, Khan et al., 2005) suggests that the lowest is the degree of differentiation of malignant cells the highest is their ability to take-up 18FDG at PET scan.

Facilitative glucose transporters (GLUTs) are transmembrane proteins responsible to introduce glucose into cells using the natural gradient existing between the extracellular and intracellular compartments. Genes encoding for these transporters belong to the solute carrier 2A family and are classified in three groups: class I (GLUT1GLUT4), class II which includes the fructose transporter GLUT5 and isoforms GLUT7, 
GLUT9, GLUT11. Class III (GLUT6, GLUT8, GLUT10, GLUT12 and the $\mathrm{H}^{+} / m y o-$ inositol transporter HMIT) (Joost et al., 2002, Joost and Thorens, 2001, Macheda et al., 2005). Since the enhanced ability in glucose uptake of tumor cells correlates with an increased expression of GLUTs, these transporters have been characterized in various tumor cell lines and in particular in lines derived from breast cancer (Macheda et al., 2005). Up to date, only two tumoral thyroid cell lines TPC-1 (papillary thyroid carcinoma) and FTC-133 (follicular thyroid carcinoma), have been analyzed for the expression of few GLUT isoforms (Matsuzu et al., 2005). Scanty data are available regarding the expression of GLUT1 in thyroid tumors, generally showing higher expression levels in differentiated thyroid tumors with poor prognosis when compared with well-differentiated tumors, benign tumors and normal thyroid tissues (Haber et al., 1997, Matsuzu et al., 2004, Schonberger et al., 2002). Interestingly, other than GLUT1, also GLUT3 has been shown to have a higher, although not significantly, expression level in thyroid tumors than in normal tissue (Matsuzu et al., 2004).

In the present study we analyzed several GLUT isoforms for their mRNA (GLUT1-4, GLUT6, GLUT8, GLUT10 and GLUT12) and protein (GLUT1 and GLUT3) expression in 5 cell lines derived from histologically different human thyroid carcinomas (ARO and FRO from ATC, NPA from papillary, WRO from follicular and TT from medullary thyroid carcinomas). We also evaluated glucose uptake levels in all cell lines taking into consideration a relation between the expression of GLUT isoforms and the degree of differentiation of the thyroid tumor cell lines studied. GLUT1 and 3 mRNA expression was evaluated also in 157 samples obtained from different thyroid tumor tissues. 


\section{MATERIALS AND METHODS}

\section{Cell lines and human thyroid tissue samples}

Experiments were conducted in five human thyroid carcinoma cell lines: FRO and ARO (anaplastic thyroid carcinoma), NPA (poorly-differentiated papillary thyroid carcinoma), WRO (follicular thyroid carcinoma) and TT (medullary thyroid carcinoma). Cells were cultured in standard conditions as previously described (Elisei et al., 2005).

A total of 157 human thyroid tissue samples were obtained at surgery and immediately frozen and kept at $-80 \mathrm{C}$ until usage. Samples studied were: 37 normal thyroid (NT), 80 papillary thyroid carcinomas (PTC), 22 medullary thyroid carcinomas (MTC), 12 follicular thyroid carcinomas (FTC) and 6 anaplastic thyroid carcinomas (ATC). The 37 NT samples were the contralateral normal thyroid tissues of 37 PTC included in the 80 cases.

\section{RNA extraction, RT-PCR and Real-time quantitative PCR for GLUTs}

Total RNA was extracted from all cell lines and tissue samples using TRIzol Reagent (Invitrogen, Milan, Italy) following manufacturer's instructions. cDNA was then synthesized and its quality was assessed by RT-PCR for the ubiquitous gene glyceraldehyde-3-phosphate dehydrogenase (GAPDH) using specific primers and conditions already reported (Elisei et al., 2005). Conventional RT-PCR for genes encoding for GLUT1, GLUT2, GLUT3, GLUT4, GLUT6, GLUT8, GLUT10 and GLUT12 was performed in cell lines using specific primers and conditions as previously described (Matsuzu et al., 2004, Rogers et al., 2003, Stuart et al., 2006). GLUT1, 
GLUT3, GLUT4, GLUT10 mRNA levels were then quantified by Real-time quantitative RT-PCR using the Real-time Sequence Detection System (PE Applied Biosystem, Foster City, CA, USA). GLUT1 and GLUT3 were studied in all histological samples. Amplification was achieved using primers and probes commercially available (Assay-onDemand Gene Expression System; Applied Biosystem, Foster City, CA, USA) and following the conditions suggested by the manufacturer. Results were then expressed as the difference of the threshold cycle $(\mathrm{Ct})$ for GLUT gene expression and mRNA level of the ubiquitous gene GAPDH $(\Delta \mathrm{Ct})$ used to normalize the results.

\section{Detection of the GLUT1 and GLUT3 proteins on cell membrane and cytoplasm}

\section{fractions}

Total proteins were isolated from all cell lines cultured in $10 \mathrm{~mm}$ cell culture dishes.

Cells were lysed in $1 \mathrm{ml}$ of Radioimmunoprecipitaction assay (RIPA) buffer (50 mmol/1 Tris-HCl, pH7.5, 150 mmol/1 NaCl, 1\% Nonidet P-40 (v/v), 0.5\% Sodium Deoxycholate $(\mathrm{w} / \mathrm{v}), 0.1 \%$ Sodium Dodecyl Sulfate $(\mathrm{w} / \mathrm{v}))$ with the addition of protease inhibitor cocktail tablets (Roche, Mannheim, Germany). Cell lysates were incubated for $30 \mathrm{~min}$ on ice and then centrifuged at $3500 \mathrm{rpm}$ for $10 \mathrm{~min}$ at $4{ }^{\circ} \mathrm{C}$. Supernatant was centrifuged at $100,000 x g$ for $1 \mathrm{~h}$ at $4^{\circ} \mathrm{C}$. Pellets containing membrane protein fractions were finally dissolved in $50 \mu \mathrm{l}$ of $1 \mathrm{X}$ PBS/0.1\% Triton X-100 (v/v) and supernatant was collected to obtain cytoplasm protein fraction. Two $\mu 1$ were used for protein quantitation by Bradford method (Bradford, 1976). Twenty $\mu \mathrm{g}$ of both protein fractions were subjected to SDSPAGE on a $12 \%$ Acrylamide (v/v) (Bio-Rad Laboratories, Hercules CA, USA) gel and transferred on Hybond-C Extra nitrocellulose membrane (Amersham Bioscences (GE 
Healthcare), Buckinghamshire, UK). After the transfer, membranes were incubated over night at $4^{\circ} \mathrm{C}$ in a 1:1000 dilution of a Rabbit Polyclonal antibody against GLUT1 (Abcam, Cambridge, UK) or $0.5 \mu \mathrm{g} / \mu 1$ of a Rabbit Polyclonal antibody against GLUT3 (Abcam, Cambridge, UK). Equal Loading amount was evaluated using a Rabbit polyclonal antibody against $\beta$-actin (Sigma Aldrich, Saint Louis, MO, USA). Mouse Anti-Rabbit IgG-HRP conjugated (Santa Cruz Biotechnology, Santa Cruz, CA, USA) at 1:1000 dilution was used in all experiments as secondary antibody. Finally, detection was performed using Immun-Star ${ }^{\mathrm{TM}}$ HRP Substrate kit (Bio-Rad Laboratories, Hercules CA, USA).

\section{${ }^{3}$ H-Deoxy-Glucose Uptake Experiments}

For glucose uptake experiments, cells were plated in 24-well plates at a density of $1.5 \times 10^{5}$ cells/well 2 days prior the uptake experiment and allowing cells to be almost confluent for the day of the experiment. Cells were quickly rinsed in $0.9 \% \mathrm{NaCl}(\mathrm{w} / \mathrm{v})$ solution and $0.5 \mathrm{ml}$ of Uptake Buffer (HBSS, 0.5\% BSA (w/v), 10 mmol/l HEPES (w/v), pH7.4) containing $1 \mu \mathrm{Ci}$ of 2-Deoxy-D-[1- $\left.{ }^{3} \mathrm{H}\right]$-glucose (Amersham Bioscences (GE Healthcare), Buckinghamshire, UK) was added on each well. ${ }^{3} \mathrm{H}-\mathrm{DG}$ was allowed to accumulate into cells for $2 \mathrm{~h}$ in an incubator at $37^{\circ} \mathrm{C}$ and $5 \% \mathrm{CO}_{2}$. Finally, cells were rinsed 3 times in ice-cold Uptake Buffer and solubilized in $0.5 \mathrm{ml}$ of RIPA buffer. In order to measure incorporated radioactivity, $0.45 \mathrm{ml}$ of each sample were removed and counted in a liquid scintillation $\beta$-counter (LKB Wallac, Turku, Finland). Twenty $\mu 1$ of each sample were used for protein quantity determination (Bradford, 1976). All experiments were conducted in triplicate for each cell line and, in order to study the 
specificity of the glucose transporter-mediated uptake we incubated cells from 2 wells in the same conditions described but with the addition of $0.05 \mathrm{mmol} / \mathrm{l}$ of cytochalasin B (Sigma Aldrich, Saint Louis, MO, USA) for FRO, WRO, NPA and TT cell lines. A higher concentration of cytochalasin B $(1.5 \mathrm{mmol} / \mathrm{l})$ was used to inhibit the uptake in ARO cell line. Radioactivity values in cpm (counts per minute) were normalized with the value of protein concentration and results were expressed as fmol ${ }^{3} \mathrm{H}-\mathrm{DG} / \mathrm{mg}$ protein.

\section{Statistic Analysis}

All statistical evaluation was performed using paired and un-paired t-test. Differences were considered significant when $P$ value was less than 0.05 . 


\section{RESULTS}

\section{Qualitative RT-PCR and Real-time quantitative RT-PCR in thyroid tumor cell lines.}

Qualitative RT-PCR was used to study mRNA expression of GLUT1-4, GLUT6, GLUT8, GLUT10 and GLUT12 in the five thyroid carcinoma cell lines. Positive detection of GAPDH in all samples demonstrated a good quality cDNA and negative controls, in which cDNA template was omitted, showed no contamination by genomic DNA. As shown in Fig. 1, the isoforms GLUT1-3 were expressed in all cell lines while GLUT4, GLUT6 and GLUT8 showed extremely weak expression. By contrast, GLUT10 showed quite strong expression in all cell lines except for TT. GLUT12 was expressed in anaplastic thyroid carcinoma cell lines FRO and ARO and medullary thyroid carcinoma cell line TT but its expression was negligible in WRO and NPA.

As shown in Table 1, the quantitative analysis of GLUT1, GLUT3, GLUT4, and GLUT10 mRNA showed high levels of expression of both GLUT1 and GLUT3, but not of GLUT4 and GLUT10, in all cell lines.

When comparing the levels of expression of GLUT1 with those of GLUT3 in the cell lines (Fig 2A), we found that GLUT1 expression levels were significantly higher in ARO and FRO cell lines ( $p<0.0001$ and $p<0.02$, respectively), similar in WRO and NPA and lower in TT cell line. In particular, ARO showed the highest level of expression of GLUT1 and the lowest level of expression of GLUT3 when compared with the other cell lines ( $p<0.0003$ and $p<0.0001$, respectively) (Fig $2 \mathrm{~B}$ ) When cell lines where considered according to their degree of de-differentiation $(A R O>F R O>W R O \geq N P A>T T)$ a mRNA 
degree of expression levels was observed with a decreasing and increasing pattern of mRNA expression levels of GLUT1 and GLUT3 respectively (Fig 2B).

\section{GLUT1 and GLUT3 mRNA levels in human thyroid tissue samples.}

As shown in Fig. 3A, the paired t-test analysis of GLUT1 and GLUT3 mRNA expression in the 37 cases of PTC in which we could analyze both the normal and the tumoral tissues, demonstrated that GLUT1 mRNA was significantly more expressed in tumoral than in contralateral normal thyroid tissues $(p<0.0001)$ while GLUT3 mRNA was only slightly higher.

The comparison of the mRNA levels of the two GLUT isoforms in the different thyroid tumor histotypes (PTC, FTC, MTC and ATC) and in the normal tissues (NT) showed that while in the latter GLUT1 was significantly less expressed than GLUT3, the opposite happened in PTC, FTC, MTC and ATC although this difference was significant only in PTC (Fig.3B).

As far as the expression of the two isoforms in different histotypes was concerned, both GLUT1 and GLUT3 showed a slightly higher expression in anaplastic than in well differentiated (PTC and FTC) thyroid tumors (Fig.3C).

\section{Analysis of GLUT1 and GLUT3 proteins on cell membrane and cytoplasm fractions.}

GLUT1 and GLUT3 proteins were studied by Western blot analysis on cell membrane and cytoplasm protein fractions. As shown in Fig. 4, GLUT1 protein revealed a very strong band with a molecular weight of $55 \mathrm{kDa}$ in $\mathrm{ARO}$ cell membrane and cytoplasm 
fractions, while a less intense band was observed on both protein fractions of the other anaplastic thyroid carcinoma cell line FRO. On the other hand, GLUT1 protein appeared to be virtually absent on WRO and NPA membranes although the protein was present in the corresponding cytoplasm compartment. GLUT1 protein staining was not visible in TT cell line, neither in membrane nor in cytoplasm fractions.

The GLUT3 protein, corresponding to a band with molecular weight of $48 \mathrm{kDa}$, was present in all cytoplasm protein fractions while it was present only in membrane protein fractions obtained from NPA and WRO. As shown in Fig 4, ARO, FRO and TT cell lines membrane protein fractions were virtually or completely negative for GLUT3.

\section{${ }^{3}$ H-DG Uptake Experiments}

As shown in Fig 5, the experiments for ${ }^{3} \mathrm{H}$-Deoxy-Glucose cell uptake showed different glucose uptake levels in cell lines analyzed: NPA showed the highest level (4000.4 fmol ${ }^{3} \mathrm{H}-\mathrm{DG} / \mathrm{mg}$ protein) followed by WRO (3567.0 fmol ${ }^{3} \mathrm{H}-\mathrm{DG} / \mathrm{mg}$ protein), ARO (2300.5 fmol ${ }^{3} \mathrm{H}-\mathrm{DG} / \mathrm{mg}$ protein) and FRO (2156.4 fmol ${ }^{3} \mathrm{H}-\mathrm{DG} / \mathrm{mg}$ protein). TT cell line uptake was very low (530.6 fmol ${ }^{3} \mathrm{H}-\mathrm{DG} / \mathrm{mg}$ protein). The inhibition of the uptake by cytochalasin B demonstrated that the uptake was specifically glucose transportermediated in all cell lines. The need to use a higher concentration of cytochalasin B to inhibit the uptake in ARO cell line $(1.5 \mathrm{mmol} / 1 \mathrm{vs} 0.05 \mathrm{mmol} / \mathrm{l}) \mathrm{might}$ be related to the higher levels of expression of the GLUT1. 


\section{DISCUSSION}

In the present study we observed that all thyroid tumors derived cell lines studied (ARO, FRO, NPA, WRO and TT) showed a quite heterogeneous expression pattern for different GLUT isoforms when analyzed by conventional RT-PCR. However, the quantitative Real-time RT-PCR analysis of GLUTs showed that anaplastic carcinoma cell line ARO had a significantly higher amount of GLUT1 when compared with all other cell lines. At variance, both NPA and TT cell lines, arising from more differentiated thyroid carcinomas such as papillary and medullary, showed lower levels of GLUT1. This finding is in keeping with the previously reported observation that GLUT1 overexpression correlates with more de-differentiated forms of thyroid tumor (Schonberger et al., 2002, Stokkel et al., 2006) that are, indeed, those with a higher ability to take-up 18 FDG (Conti et al., 1999, Khan et al., 2005).

As opposite to GLUT1, quantitative Real time RT-PRC showed that GLUT3 expression levels were very low in anaplastic ARO cell line but significantly higher in all other cell lines, in particular in NPA and TT cell lines. These results suggest that the expression levels of GLUT1 and GLUT3 have an inverse correlation with the degree of cell differentiation.

The ${ }^{3} \mathrm{H}-\mathrm{DG}$ uptake experiments demonstrated that, despite the highest levels of GLUT1 expression and its correct localization on the plasma membrane, anaplastic ARO and FRO cell lines showed lower uptake ability when compared with papillary NPA and follicular WRO cell lines. This discrepancy between GLUT1 expression levels and ${ }^{3} \mathrm{H}-$ 
DG uptake could be due to a defect of N-glycosylation status as already observed in primary anaplastic thyroid cell lines by other authors (Samih et al., 2003).

Since the level of expression of GLUT1 is lower in both NPA and WRO, their highest ability to take-up ${ }^{3} \mathrm{H}$-Deoxy-Glucose could be correlated with both the highest levels of expression of GLUT3 and the correct plasma membrane localization of the protein, which has been demonstrated to have a very high affinity for glucose analogs, especially at low glucose concentrations (Burant and Bell, 1992, Gould et al., 1991). The crucial role of a correct plasma membrane localization of GLUT3 protein for its ability to takeup ${ }^{3} \mathrm{H}$-Deoxy-Glucose was clearly demonstrated in TT cell line that expressed GLUT3 mRNA but did not display a plasma membrane protein and were, indeed, unable to incorporate the glucose tracer. The presence of GLUT3 transcript in the absence of a functional protein has been previously reported in other human tumors (Boado et al., 1994, Higashi et al., 1998, Yamamoto et al., 1990).

As far as the GLUT1 and GLUT3 mRNA expression in thyroid tumor is concerned, our data support the results of the few reports that have been published up to date (Haber et al., 1997, Matsuzu et al., 2004, Schonberger et al., 2002) which showed a significant increase of GLUT1 and a slightly increase of GLUT3 mRNA levels in malignant thyroid tissues when compared to normals. The evidence of a decreasing pattern of mRNA expression levels of GLUT1 in cell lines accordingly to their pattern of dedifferentiation was confirmed in human thyroid tumors with ATC showing a higher expression than PTC and FTC. To our knowledge, no data have been yet reported on the relationship between GLUT3 and the tumor differentiation degree. Unfortunately our findings on cell lines were not confirmed in the tumoral tissues that showed a higher levels of expression 
of GLUT3 in ATC than in PTC and FTC. This controversial data are difficult to be explained but we should take into account that the number of ATC was quite small and that not always in vitro models are representative of what really happens in vivo. On this regard, it is well known that cell lines can change their features as consequence of a long term in vitro evolution (van Staveren et al., 2007).

In conclusion, we demonstrated that GLUT1 and GLUT3 are the most important glucose transporters involved in the thyroid tumoral cell metabolism. In particular GLUT1 represents the main GLUT isoform in the anaplastic ARO and FRO cell lines while GLUT3 appears to be predominant in more differentiated thyroid tumor cell lines such as papillary NPA and follicular WRO. However the analysis of GLUT1 and GLUT3 mRNA expression in human thyroid tumors confirmed that only GLUT1 was significantly more expressed in malignant than in the corresponding normal tissues and that its expression is higher in more aggressive histotypes. The clinical meaning and the role in 18-FDG uptake of GLUT3 remains to be established. 


\section{Acknowledgement:}

We thank Dr Suzanne Rogers from the Department of Medicine, St. Vincent's Hospital, University of Melbourne, Australia for the information on GLUT12 RT-PCR conditions.

Dr Raffaele Ciampi is recipient of a fellowship from FIRC (Fondazione Italiana per la Ricerca sul Cancro).

The Department of Endocrinology is a WHO Collaborating center for the diagnosis and treatment of thyroid cancer and other thyroid diseases.

This study was supported by grants from “Ministero dell'Istruzione dell'Università e della Ricerca (MIUR)” and Associazione Italiana per la Ricerca sul Cancro (AIRC).

The authors declare that there is no conflict of interest that would prejudice the impartiality of this scientific work reported. 


\section{REFERENCES}

Boado, R.J., Black, K.L. and Pardridge, W.M. (1994) Gene expression of GLUT3 and GLUT1 glucose transporters in human brain tumors. Brain Res Mol Brain Res 27, $51-7$.

Bradford, M.M. (1976) A rapid and sensitive method for the quantitation of microgram quantities of protein utilizing the principle of protein-dye binding. Anal Biochem $72,248-54$.

Burant, C.F. and Bell, G.I. (1992) Mammalian facilitative glucose transporters: evidence for similar substrate recognition sites in functionally monomeric proteins. Biochemistry 31, 10414-20.

Conti, P.S., Durski, J.M., Bacqai, F., Grafton, S.T. and Singer, P.A. (1999) Imaging of locally recurrent and metastatic thyroid cancer with positron emission tomography. Thyroid 9, 797-804.

Elisei, R., Vivaldi, A., Agate, L., Ciampi, R., Molinaro, E., Piampiani, P., Romei, C., Faviana, P., Basolo, F., Miccoli, P., Capodanno, A., Collecchi, P., Pacini, F. and Pinchera, A. (2005) All-trans-retinoic acid treatment inhibits the growth of retinoic acid receptor beta messenger ribonucleic acid expressing thyroid cancer cell lines but does not reinduce the expression of thyroid-specific genes. J Clin Endocrinol Metab 90, 2403-11.

Frilling, A., Tecklenborg, K., Gorges, R., Weber, F., Clausen, M. and Broelsch, E.C. (2001) Preoperative diagnostic value of [(18)F] fluorodeoxyglucose positron 
emission tomography in patients with radioiodine-negative recurrent welldifferentiated thyroid carcinoma. Ann Surg 234, 804-11.

Gould, G.W., Thomas, H.M., Jess, T.J. and Bell, G.I. (1991) Expression of human glucose transporters in Xenopus oocytes: kinetic characterization and substrate specificities of the erythrocyte, liver, and brain isoforms. Biochemistry 30, 513945.

Grunwald, F., Kalicke, T., Feine, U., Lietzenmayer, R., Scheidhauer, K., Dietlein, M., Schober, O., Lerch, H., Brandt-Mainz, K., Burchert, W., Hiltermann, G., Cremerius, U. and Biersack, H.J. (1999) Fluorine-18 fluorodeoxyglucose positron emission tomography in thyroid cancer: results of a multicentre study. Eur J Nucl Med 26, 1547-52.

Haber, R.S., Weiser, K.R., Pritsker, A., Reder, I. and Burstein, D.E. (1997) GLUT1 glucose transporter expression in benign and malignant thyroid nodules. Thyroid 7, 363-7.

Hatanaka, M. (1974) Transport of sugars in tumor cell membranes. Biochim Biophys Acta 355, 77-104.

Higashi, T., Tamaki, N., Torizuka, T., Nakamoto, Y., Sakahara, H., Kimura, T., Honda, T., Inokuma, T., Katsushima, S., Ohshio, G., Imamura, M. and Konishi, J. (1998) FDG uptake, GLUT-1 glucose transporter and cellularity in human pancreatic tumors. J Nucl Med 39, 1727-35.

Isselbacher, K.J. (1972a) Increased uptake of amino acids and 2-deoxy-D-glucose by virus-transformed cells in culture. Proc Natl Acad Sci U S A 69, 585-9. 
Isselbacher, K.J. (1972b) Sugar and amino acid transport by cells in culture--differences between normal and malignant cells. N Engl J Med 286, 929-33.

Joost, H.G., Bell, G.I., Best, J.D., Birnbaum, M.J., Charron, M.J., Chen, Y.T., Doege, H., James, D.E., Lodish, H.F., Moley, K.H., Moley, J.F., Mueckler, M., Rogers, S., Schurmann, A., Seino, S. and Thorens, B. (2002) Nomenclature of the GLUT/SLC2A family of sugar/polyol transport facilitators. Am J Physiol Endocrinol Metab 282, E974-6.

Joost, H.G. and Thorens, B. (2001) The extended GLUT-family of sugar/polyol transport facilitators: nomenclature, sequence characteristics, and potential function of its novel members (review). Mol Membr Biol 18, 247-56.

Khan, N., Oriuchi, N., Higuchi, T. and Endo, K. (2005) Review of fluorine-18-2-fluoro2-deoxy-D-glucose positron emission tomography (FDG-PET) in the follow-up of medullary and anaplastic thyroid carcinomas. Cancer Control 12, 254-60.

Kresnik, E., Gallowitsch, H.J., Mikosch, P., Stettner, H., Igerc, I., Gomez, I., Kumnig, G. and Lind, P. (2003) Fluorine-18-fluorodeoxyglucose positron emission tomography in the preoperative assessment of thyroid nodules in an endemic goiter area. Surgery 133, 294-9.

Macheda, M.L., Rogers, S. and Best, J.D. (2005) Molecular and cellular regulation of glucose transporter (GLUT) proteins in cancer. J Cell Physiol 202, 654-62.

Matsuzu, K., Segade, F., Matsuzu, U., Carter, A., Bowden, D.W. and Perrier, N.D. (2004) Differential expression of glucose transporters in normal and pathologic thyroid tissue. Thyroid 14, 806-12. 
Matsuzu, K., Segade, F., Wong, M., Clark, O.H., Perrier, N.D. and Bowden, D.W. (2005) Glucose transporters in the thyroid. Thyroid 15, 545-50.

Plotkin, M., Hautzel, H., Krause, B.J., Schmidt, D., Larisch, R., Mottaghy, F.M., Boemer, A.R., Herzog, H., Vosberg, H. and Muller-Gartner, H.W. (2002) Implication of 218fluor-2-deoxyglucose positron emission tomography in the follow-up of Hurthle cell thyroid cancer. Thyroid 12, 155-61.

Rogers, S., Docherty, S.E., Slavin, J.L., Henderson, M.A. and Best, J.D. (2003) Differential expression of GLUT12 in breast cancer and normal breast tissue. Cancer Lett 193, 225-33.

Samih, N., Hovsepian, S., Notel, F., Prorok, M., Zattara-Cannoni, H., Mathieu, S., Lombardo, D., Fayet, G. and El-Battari, A. (2003) The impact of N- and Oglycosylation on the functions of Glut-1 transporter in human thyroid anaplastic cells. Biochim Biophys Acta 1621, 92-101.

Schonberger, J., Ruschoff, J., Grimm, D., Marienhagen, J., Rummele, P., Meyringer, R., Kossmehl, P., Hofstaedter, F. and Eilles, C. (2002) Glucose transporter 1 gene expression is related to thyroid neoplasms with an unfavorable prognosis: an immunohistochemical study. Thyroid 12, 747-54.

Scott, A.M. (2001) Current status of positron emission tomography in oncology. Intern Med J 31, 27-36.

Stokkel, M.P., Duchateau, C.S. and Dragoiescu, C. (2006) The value of FDG-PET in the follow-up of differentiated thyroid cancer: a review of the literature. Q J Nucl Med Mol Imaging 50, 78-87. 
Strauss, L.G. and Conti, P.S. (1991) The applications of PET in clinical oncology. J Nucl Med 32, 623-48; discussion 649-50.

Stuart, C.A., Yin, D., Howell, M.E., Dykes, R.J., Laffan, J.J. and Ferrando, A.A. (2006) Hexose transporter mRNAs for GLUT4, GLUT5, and GLUT12 predominate in human muscle. Am J Physiol Endocrinol Metab 291, E1067-73.

van Staveren, W.C., Solis, D.W., Delys, L., Duprez, L., Andry, G., Franc, B., Thomas, G., Libert, F., Dumont, J.E., Detours, V. and Maenhaut, C. (2007) Human thyroid tumor cell lines derived from different tumor types present a common dedifferentiated phenotype. Cancer Res 67, 8113-20.

Yamamoto, T., Seino, Y., Fukumoto, H., Koh, G., Yano, H., Inagaki, N., Yamada, Y., Inoue, K., Manabe, T. and Imura, H. (1990) Over-expression of facilitative glucose transporter genes in human cancer. Biochem Biophys Res Commun 170, 223-30. 


\section{FIGURE LEGENDS}

\section{FIGURE 1}

Conventional RT-PCR results for GLUT1-4, GLUT6, GLUT8, GLUT10 and GLUT12 genes in thyroid tumor cell lines. All cell lines showed the expression of GLUT1, GLUT2 and GLUT3 genes. GLUT4, GLUT6 and GLUT8 were weakly or not expressed while GLUT10 showed expression in all cell lines but TT. GLUT12 showed strong expression in ARO and TT, a weak expression in WRO and NPA and it was not expressed in WRO and NPA.

\section{FIGURE 2}

Panel A): GLUT1 and GLUT3 mRNA expression levels obtained by quantitative Realtime RT-PCR analysis. All data were means \pm SD of two experiments in triplicate. Both in ARO and FRO cell lines, GLUT1 expression level was significantly higher than those of GLUT3 ( $<<0.0001$ and $\mathrm{p}<0.02$ respectively). This difference was not found in the differentiated WRO, NPA and TT cell lines.

Panel B): GLUT1 and GLUT3 mRNA expression levels were significantly higher $(\mathrm{p}<0.0003)$ and lower $(\mathrm{p}<0.0001)$ in ARO than in all other cell lines.

It is worth noting that, since $\Delta \mathrm{Ct}$ values are inversely correlated to mRNA levels, for a better schematic representation, the figure shows the $\Delta \mathrm{Ct}$ as $\Delta \mathrm{Ct}^{-1}$

\section{FIGURE 3}

Panel A): GLUT1 and GLUT3 mRNA expression levels in 37 papillary thyroid carcinomas (PTC) and their contralateral normal tissues (NT) showing that while GLUT1 was significantly more expressed in PTC than in NT, GLUT3 mRNA levels were only slightly higher. 
Panel B): Comparison of GLUT1 and GLUT3 mRNA expression levels in different histotypes of thyroid carcinomas: GLUT3 was the most expressed isoforms in NT $(\mathrm{p}<0.0001)$ while GLUT1 was the most expressed isoform in all different histotypes.

Panel C): Comparison between GLUT1 and GLUT3 expression levels in differentiated thyroid carcinomas (PTC, FTC) and anaplastic carcinoma (ATC): both GLUT1 and GLUT3 were more expressed in ATC than in PTC and FTC.

It is worth noting that, since $\Delta \mathrm{Ct}$ values are inversely correlated to mRNA levels, for a better schematic representation, the figure shows the $\Delta \mathrm{Ct}$ as $\Delta \mathrm{Ct}^{-1}$

\section{FIGURE 4}

Western blot analysis showing GLUT1 and GLUT3 proteins in membrane and cytoplasm fractions of thyroid carcinoma cell lines. Both GLUT1 and GLUT3 proteins were present in cytoplasm fractions of FRO, NPA, WRO and ARO but not TT. In membrane fractions, GLUT1 protein was strongly present in ARO membranes and, although to a lesser extent, in FRO. GLUT1 was not present in TT, NPA and WRO membranes. GLUT3 protein was present with a strong $48 \mathrm{kDa}$ band in NPA, WRO and with a very faint band in ARO. On the bottom lane, $\beta$-actin staining confirmed equal loading.

\section{FIGURE 5}

Results of the ${ }^{3} \mathrm{H}-\mathrm{DG}$ uptake and cytochalasin $\mathrm{B}$ inhibition experiments on thyroid carcinoma cell lines: NPA cell line showed the highest uptake value followed by WRO, FRO, ARO and TT. Results were expressed in $\mathrm{fmol}{ }^{3} \mathrm{H}-\mathrm{DG} / \mathrm{mg}$ protein and represented the mean value of two separate experiments conducted in triplicate. The ${ }^{3} \mathrm{H}-\mathrm{DG}$ uptake was inhibited in all cell when cytochalasin $\mathrm{B}$ was added. * A higher concentration of cytochalasin B (1.5 mmol/l) was used for the inhibition of ARO cell line. 
TABLE 1 Real-time RT-PCR results for GLUT1, 3, 4 and $10(\Delta \mathrm{Ct} \pm \mathrm{SD})$

\begin{tabular}{|l|c|c|c|c|}
\hline & $\begin{array}{c}\text { GLUT1 } \\
(\Delta \mathrm{C} t \pm \mathrm{SD})\end{array}$ & $\begin{array}{c}\text { GLUT3 } \\
(\Delta \mathrm{Ct} \pm \mathrm{SD})\end{array}$ & $\begin{array}{c}\text { GLUT4 } \\
(\Delta \mathrm{C} \pm \mathrm{SD})\end{array}$ & $\begin{array}{c}\text { GLUT10 } \\
(\Delta \mathrm{C} \pm \mathrm{SD})\end{array}$ \\
\hline FRO & $4.33 \pm 0.57$ & $7.61 \pm 0.60$ & $32.62 \pm 0.83$ & $26.83 \pm 1.03$ \\
\hline WRO & $4.82 \pm 0.41$ & $5.02 \pm 0.43$ & $31.02 \pm 0.62$ & $25.45 \pm 0.78$ \\
\hline ARO & $1.20 \pm 0.27$ & $19.30 \pm 0.30$ & $33.32 \pm 0.41$ & $25.34 \pm 0.51$ \\
\hline NPA & $6.04 \pm 0.49$ & $5.86 \pm 0.51$ & $32.49 \pm 0.71$ & $27.42 \pm 0.87$ \\
\hline
\end{tabular}

* $\Delta \mathrm{Ct}$ is the difference between the threshold cycle $(\mathrm{Ct})$ relative to GLUT gene and the Ct relative to GAPDH used to normalize the results, as described in Materials and Methods. $\Delta \mathrm{Ct}$ values are inversely correlated to mRNA levels. 


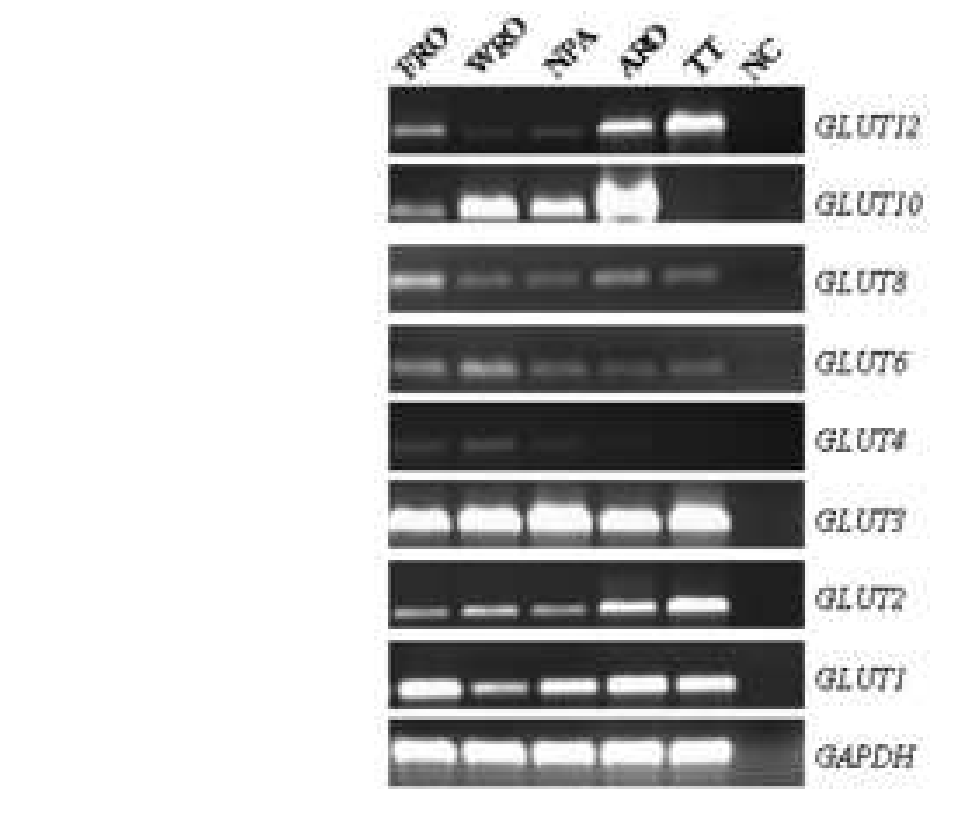

\section{FIG. 1}




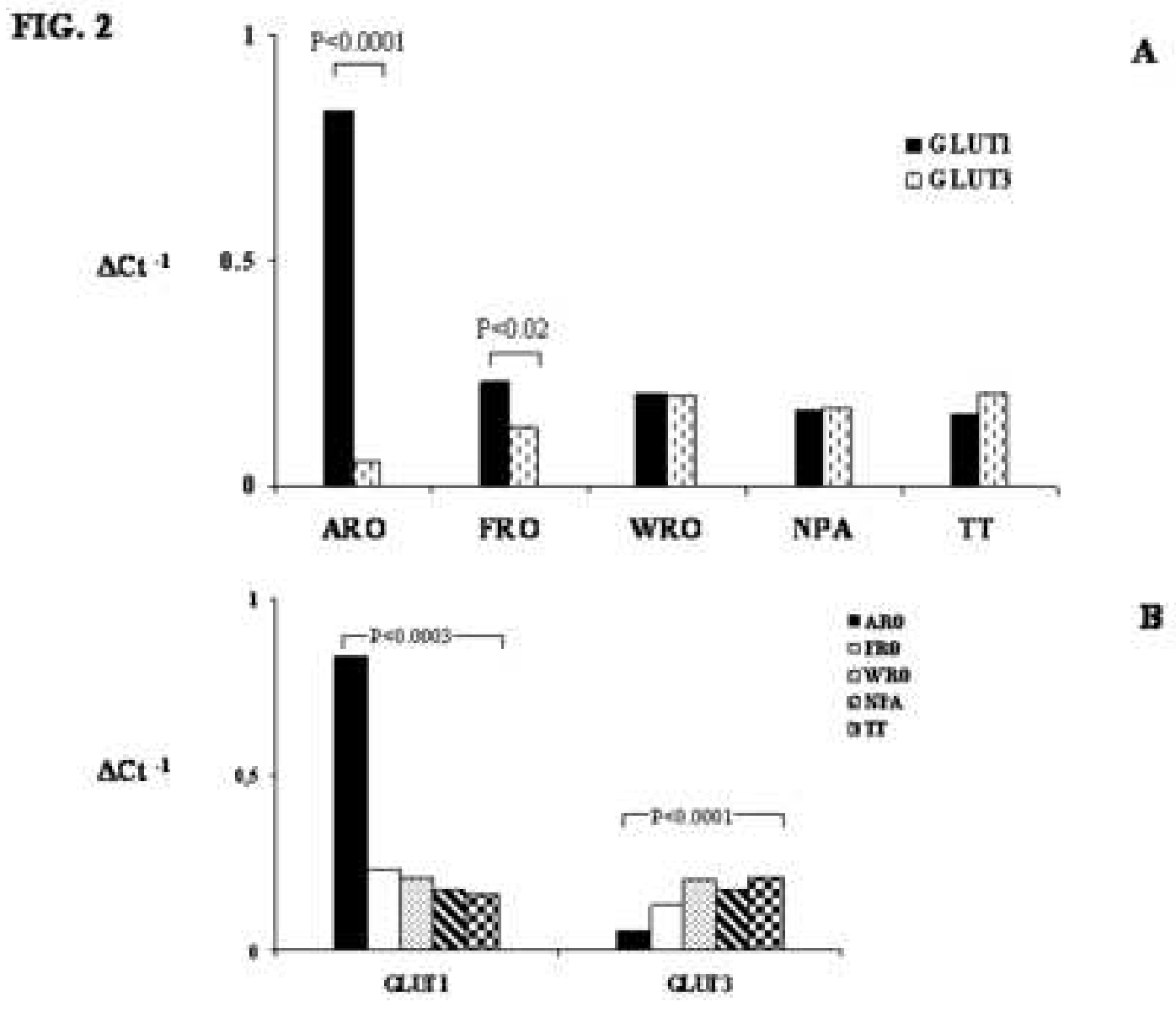

A

B

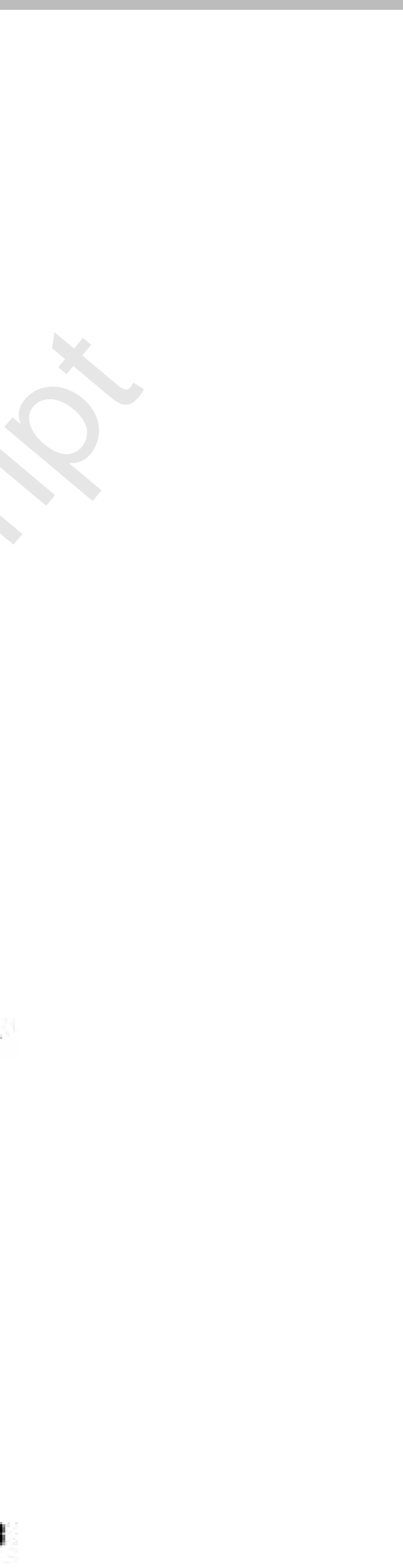


FIG. 3

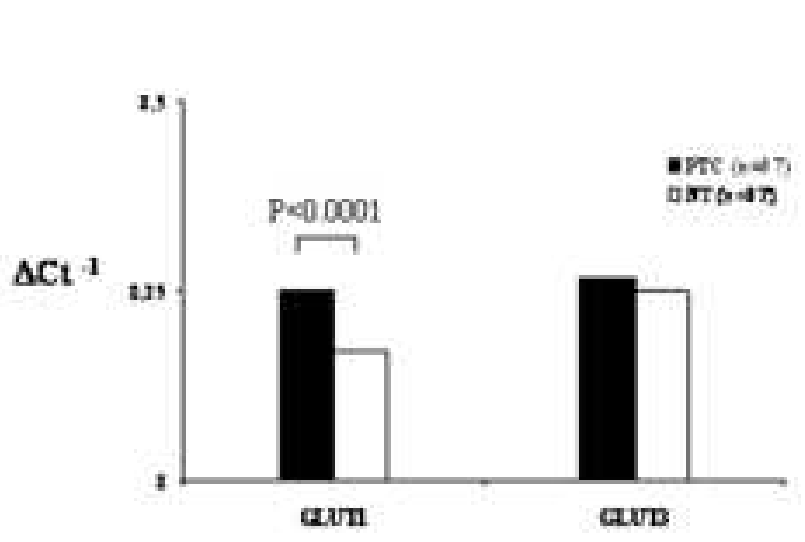

B

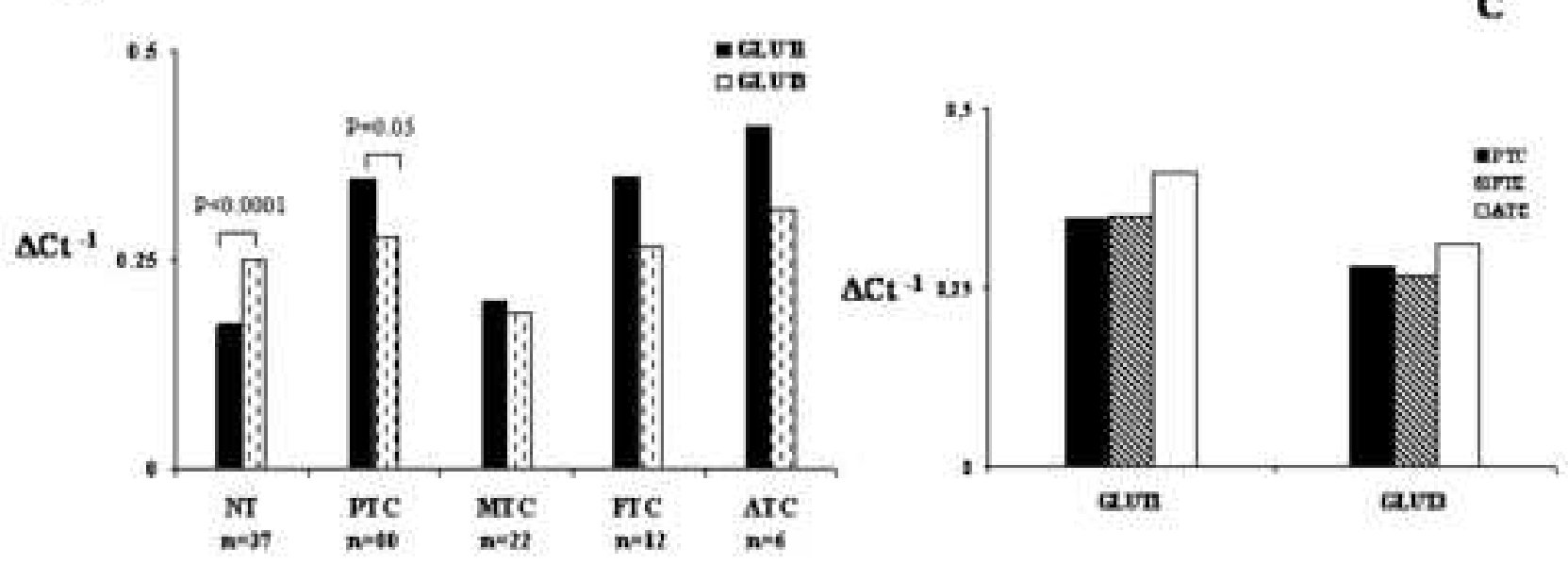

Page 26 of 28 


\title{
FIG. 4
}

membranes
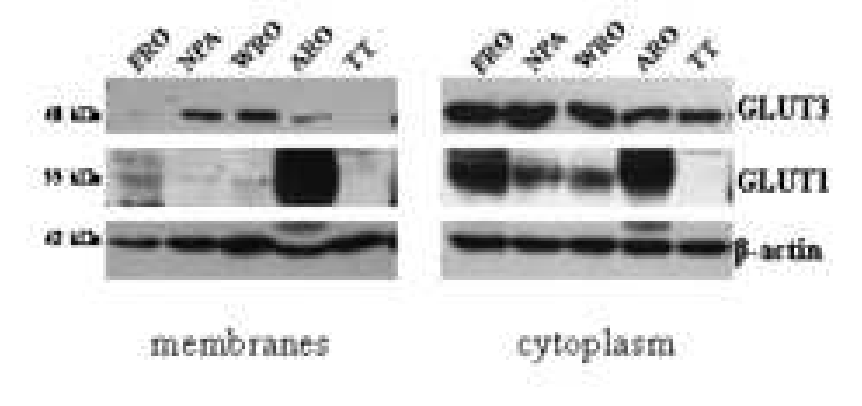

cytoplasm

\author{
memoranes
}




\section{FIG. 5}

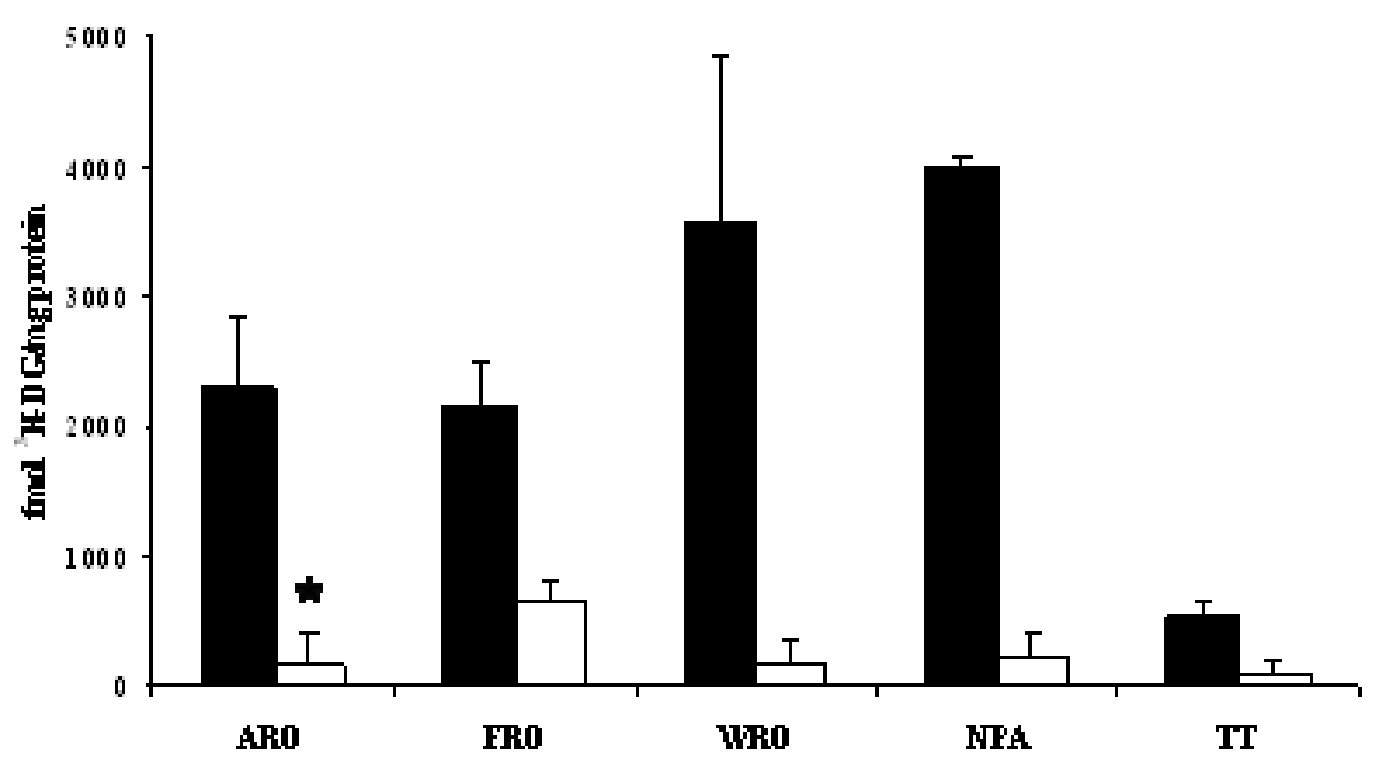

